\title{
A case for redistribution? \\ Income inequality and wealth concentration in the recent crisis
}

\author{
Thomas Goda \\ Universidad EAFIT \\ Özlem Onaran \\ University of Greenwich \\ Engelbert Stockhammer \\ Kingston University
}

Year: 2014

No. GPERC05 


\begin{abstract}
Several Nobel laureates economists have called for redistributive policies. This paper shows that there is a strong case for redistributive policies because the global increase of income inequality and wealth concentration was an important driver for the financial and Eurozone crisis. The high levels of income inequality resulted in balance of payment imbalances and rising debt levels. Rising wealth concentration contributed to the crisis because the increasing asset demand from the rich played a key role in the rise of the structured credit market and enabled poor and middle-income households to accumulate increasing amounts of debt. To tame the inherent instability of the current mode of capitalism it is necessary to reduce inequality.
\end{abstract}

Keywords: Financial crisis, Eurozone crisis, distribution, income inequality, wealth concentration, redistribution

Acknowledgements: We would like to thank Maria Fernanda Quintero, Ian Geer, Matt Vidal, Photis Lysandrou and the participants of the $17^{\text {th }}$ Research Network Macroeconomics and Macroeconomic Policies conference and the XI International Colloquium of the University of Brasilia for their helpful comments.

Corresponding Author: Thomas Goda: Universidad EAFIT, School of Economics and Finance, Carrera 49 \# 7sur - 50, Medellin , Colombia; +57 42619500 - 8664; tgoda@eafit.edu.co Özlem Onaran: University of Greenwich, Business School, Park Row, Greenwich, London, SE10 9LS, UK, e-mail: o.onaran@ gre.ac.uk, phone: +44 2083318519.

Engelbert Stockhammer: Kingston University, Department of Economics, Penrhyn Road, Kingston Upon Thames, KT1 2EE, UK; +44 208417 7774; e.stockhammer@kingston.ac.uk 


\section{Introduction}

Economic inequality has become a prominent topic in public debate after the publication of Piketty's (2014) book Capital in the Twenty-First Century, which provides an overview about the global increase in income inequality and wealth concentration over the past 30 years. The last time that the topic reached such a prominence was in the 1930s when it was widely accepted that inequality was a cause for the Great Depression (Eccles, 1951; Galbraith, 1975). As a response policy makers of developed countries increased top marginal income and wealth taxes sharply, regulated markets, and strengthened the social welfare system during the middle of the twentiethcentury. The result of these policies, which went hand in hand with the post-war boom, was a sharp decline in inequality levels.

During the 1970s "[s]lower growth, higher inflation and unemployment, and falling profits and stock prices created growing discontent with the economic status quo" (Crotty, 2012, p.83). This discontent by the ruling elite contributed to a push towards neoliberal policies so that most countries deregulated markets, strengthened corporate control and lowered personal and corporate taxes, resulting in a decline in labor's bargaining power and a polarization of income to levels not seen since the 1930s (Stiglitz, 2012; Vidal, 2013; Piketty, 2014). The recent rise in income inequality and wealth concentration led Piketty (2014) to the conclusion that the introduction of a global progressive capital tax is necessary and also was the reason that several Nobel laureates economists made a call for more progressive income, estate and consumption taxes (Shiller, 2012; Stiglitz, 2012; Solow, 2014). 
One justification for such redistributional policies could be that the increase in inequality was a major contributing factor to the financial crisis of $2007-2009^{1}$. Such a claim has been made by authors like Kumhof et al. (2012), Stiglitz (2012), Behringer and van Treeck (2013), and van Treeck (2014), who argue that rising income inequality was a root cause for the rapid growth of the US non-prime mortgage market and the global balance of payment imbalances that contributed to the Great Recession. Moreover, Lysandrou (2011a; 2011b), Milanovic (2011), Wisman (2013), and Goda and Lysandrou (2014) point out that the rise in the absolute concentration of wealth was an important contributing factor to the crisis, because the growing demand from very rich individuals for investible securities was a major driver behind the growth of the structured credit market.

However, these claims have remained to date a minority view. The debates about the financial crisis have mainly focused on the regulation of global financial markets (Kregel, 2008; Major, 2012; Thiemann, 2014), central bank policy failures (Taylor, 2008; Golub et al., 2014), market failures (Ashcraft and Schuermann, 2008) and irrational behavior (Akerlof and Shiller, 2009). The aim of this paper is to analyze if the rise in inequality was a primary cause for the malfunctioning of the financial sector. To grasp the complex relationship between inequality and financial stability we will provide a framework that takes both sides of the inequality coin, income and wealth, equally into account. To the best of our knowledge, this is the first paper in the literature on the crisis that combines these two dimensions of inequality. The paper is also distinct in that it analyses the financial crisis in the US as well as the sovereign debt crisis in Europe. Both

\footnotetext{
${ }^{1}$ There are other reasons why increasing inequality might be harmful, e.g. rising inequality fosters the influence on political decisions which undermines democratic institutions and diverts resources to the wealthiest sectors (Esteban and Ray, 2006; Gilens and Page, 2014).
} 
crises are interconnected, but often analyzed in isolation. We argue that the Eurozone crisis cannot be understood fully without taking into account the preceding events and the rise in inequality.

The next section shows how the financial crisis began in the market for subprime derivatives and morphed into a financial crisis, an economic crisis and, in the Eurozone, in a sovereign debt crisis. Sections three and four discuss why the recent crisis is partly result of structural problems in the global economy that arose due to increasing inequality. The third section clarifies why income inequality was a main ingredient for the emergence of debt-led and exportled growth models, and an important reason behind the rise of current account imbalances. The fourth section illustrates how absolute wealth concentration contributed to these developments and argues that increasing wealth holdings at the top were a crucial driver behind the securitization of (subprime) loans. The overall findings of the paper are consolidated in section five and, finally, section six concludes with policy recommendations.

\section{From the US subprime crisis to the global financial crisis and the Eurozone crisis}

On the $9^{\text {th }}$ of August 2007 the French bank BNP Paribas announced the complete evaporation of liquidity in the market for certain structured financial securities. The reason for this announcement was that the super senior tranches of CDOs, which ought to be safe, started to suffer losses because of rapidly rising delinquency and foreclosure rates on US subprime mortgages. The collapse of the entire CDO market, in turn, led to uncertainty and panic in the global banking sector because the 
exact extent of the balance sheet risk exposure of financial institutions was unclear for market participants (Acharya et al., 2011; Shin, 2012).

The subsequent breakdown in trust between large commercial banks (many of whom owned or sponsored investment vehicles that were directly exposed to this market segment) set in motion a liquidity-solvency crisis spiral, which in September 2008 culminated in the paralysis of the whole financial system when the world's third largest investment bank, Lehman Brothers, declared bankruptcy and the insurance company American International Group (AIG) collapsed. The following flight to safe securities caused a decline in the government bond yields in OECD countries (most notably the US, UK and Germany), and interbank lending literally stopped. The freezing of the interbank market meant that banks started to hoard liquidity, with the result that most households and firms were no longer able to get access to credit. The result was a global recession in 2009.

The final, on-going, phase of the crisis is the Eurozone crisis that started in 2010. One outcome of the financial crisis and the recession was that European governments needed to rescue two types of banks: (i) banks that bought the toxic securities that triggered the subprime crisis, and (ii) highly leveraged banks that had a maturity mismatch and could not roll-over their debt. Another outcome was that government revenues declined while spending increased due to the recession. Accordingly, public deficits and public debt increased sharply in nearly all Eurozone countries (Figure 1a). During 2008 and 2009 long-term government bond yields of these countries declined or stayed roughly stable due to the flight to safety by investors (Figure 1b-c). However, in 2010 this situation started to change because investors became concerned about the sustainability of public finances in the Eurozone, leading to a rise in the refinancing costs for all countries. This increase in yields was relatively minor and temporary in those countries that had export-surpluses, 
whereas Greece, Ireland, Portugal, and to a lesser extent Spain - the so called GIPS countries experienced a longer lasting increase in risk premia (Figure 1b-c).

[Figure 1]

The GIPS countries have in common that they experienced the build-up of a real estate bubble, rapidly increasing private debt levels, and significant current account deficits (ranging from an average of $-2.1 \%$ in the case of Ireland ${ }^{2}$ to $-9.2 \%$ in the case of Portugal), which were financed by capital inflows from the rest of the world. An outcome of the 2007 crisis was that their real estate bubbles burst, which meant that some of their banks went into trouble and unemployment rates rose sharply along with a deep recession. Investors therefore increasingly feared that these countries would not be able to repay their accumulated debt, which manifested in increasing sovereign risk premia. ${ }^{3}$ The hike in interest rates made a bailout program necessary as the refinancing costs for GIPS countries became too high. The accompanying austerity measures that were required from the European Commission, the European Central Bank (ECB) and the IMF the so called Troika- were detrimental. They resulted in a decrease in domestic demand that contributed to a sharp increase in unemployment, social unrest, a long economic depression (Figure 1d), and a further rise in debt to GDP ratios (Figure 1a).

This experience stands in stark contrast to that of current account surplus countries in the Eurozone. Due to their lower (private and public) debt levels and higher competitiveness of their

\footnotetext{
${ }^{2}$ Ireland is different from the other GIPS countries in that the source of its current account deficits were repatriated profits by multinational corporations and it had trade surpluses, although these deteriorated in the 2000s.

${ }^{3}$ An important reason for the sharp increase in the yields of Greek government bonds was that prior to the crisis the Greek administration misreported budgetary data, which came out when the new government presented a deficit that was more than twice as high as expected (Hoque, 2013). Portugal also had persistent deficits prior to the crisis, while Ireland and Spain had budget surpluses and very low public debt to GDP ratios in 2007 (25\% and 36\% respectively) that only increased sharply because of the recession and the high costs of their banking bailouts (especially in Ireland).
} 
exports, investors were confident that these countries are able to repay their debt more easily. Consequently, the demand for their bonds increased again in 2011, driving down their sovereign debt costs to historically low levels (Figure 1b). Moreover, this latter group of countries engaged in a policy of modest fiscal stimulus when the recession began, which contributed to their quick recovery from the 2009 recession, although initially they were hit hard by the recession as a result of the sharp decline of their exports. This recovery was only short lived however, with the result that in 2013 the growth of all Eurozone countries was either stagnating or negative (Figure 1d).

This analysis shows that the main cause for the Eurozone crisis was not so much the lack of fiscal discipline by some countries, as argued by many mainstream analysts (see e.g. Schuknecht et al., 2011; Costa and Ricciuti, 2013), but rather the outcome of the financial crisis and the deepening of current account imbalances within the region. Structural flaws of the European Monetary Union led to an escalation of the Eurozone crisis. Among these are a lack of instruments to cope with inflation rate differentials and financial bubbles, the lack of a coordinated fiscal policy, and a central bank that is mainly concerned with inflation targeting and reluctant to act as a lender of last resort for member states (Arestis and Sawyer, 2011; Stockhammer, 2011, 2014; Sawyer, 2013). The causes of the crisis thus lie in the imbalances that Europe had built up prior to the crisis and the reason for deepening of the crisis is related to the policy regime, but the initial trigger of the Eurozone crisis was the financial crisis.

A distinctive feature of the pre-crisis era was an increase in income inequality within developed countries (Goda, 2013; Piketty, 2014) as well as a global increase in absolute wealth concentration at the top (Goda, 2014). While it is widely acknowledged that distributional issues have to figure somewhere in the plot of these events, the question arises if income inequality and 
wealth concentration was at the very root of the recent crisis. The remainder of this paper intends to answer this question.

\section{Income inequality and debt- and export-led growth}

There has been a significant decline in the share of wages in GDP in both the developed and developing countries since the 1970s (Onaran and Galanis, 2012; OECD 2012; Stockhammer, 2013b). Figure 2 shows the adjusted wage share in national income in the developed world. ${ }^{4}$ The share of wages has fallen by $10 \%$-points in the Eurozone, and even more in Japan. In the English speaking countries a sharp polarization of personal income distribution and a rise in the remuneration of top managers has occurred since the 1980s (Atkinson et al., 2011). As can be seen in Figure 3, the share of the top $1 \%$ of the income distribution in the US has reached $18.3 \%$ of GDP in 2007 prior to the crisis exceeding the levels before World War I and the Great Depression; the UK followed a similar pattern. Since managerial wages are part of wages, this has led to a more modest decline in the wage share in the US and the UK compared to continental Europe. Top income shares did not experience the same surge in continental Europe, but in Germany a significant low wage segment emerged similar to the US and the UK (Vidal, 2013).

[Figure 2]

[Figure 3]

\footnotetext{
${ }^{4}$ Wages are adjusted labour compensation (real compensation per employee multiplied by total employment).
} 
Whether the rise in personal income inequality was caused by a rise in top incomes or the generation of a low wage sector, in all the countries, a trend towards greater inequality in personal income distribution went along with the fall in the wage share. These developments indicate a clear reversal of the trends towards relatively egalitarian income distribution during the post-war era. Daudey and Garcia-Penalosa (2007), Dafermos and Papatheodorou (2011), and Wolff and Zacharias (2013) show that the rise of personal income inequality is related to changes in the wage share. The distribution of personal income depends on the distribution of labor and capital endowments, and the way in which aggregate output is shared between the two. If the distribution of capital is more unequal than that of labor, a decrease in the labor share would increase personal income inequality.

A fall in the wage share reflects falling unit labor costs, and increasing profitability. Mainstream economic policy, informed by neoclassical economics, thus expects the decline in the wage share to be associated with stronger growth and employment. However, as can be seen from the post-1980s average annual growth rates in GDP (Table 1), this has not been the case, in particular with the hindsight of the lost output since the Great Recession.

\section{[Table 1]}

This is a puzzle for mainstream economics, which focuses only on the role of wages as a cost item. But Post-Keynesian/Post-Kaleckian models ${ }^{5}$ suggest that wages have a dual role as a source of demand as well. A rise in inequality in the form of a fall in the share of wages will, other things

\footnotetext{
${ }^{5}$ Post-Keynesian economics builds on Keynesian theory of effective demand. It deviates from mainstream Keynesianism in that it regards Keynes' work as break with the neoclassical traditions. In particular Post-Keynesians rejects the need for microfoundations and the marginal productivity theory of income distribution. Its monetary theory is based on the concept of fundamental uncertainty and highlights the possibility of financial crisis. It often uses class analysis as a foundation of macroeconomic analysis. Bhaduri and Marglin (1990) presents a good outline of the Post-Keynesian/Post-Kaleckian models. Lavoie (2009) and King (2002) offer introductions to Post-Keynesian theory.
} 
equal, suppress domestic consumption since the marginal propensity to consume out of wages is higher than that out of profits. ${ }^{6}$ However, it may also have a positive effect on investment due to increased profitability, and improved international competitiveness might lead to higher net exports due to lower unit labor costs. In order to assess the effects of wage moderation it is necessary to address the effects on all three components of private demand. If the differentials in marginal propensity to consume between wages and profits is relatively large, but the responsiveness of investment to profitability and exports and imports to relative price changes are low, then the total effect of the increase in the profit share on aggregate demand and hence growth would be negative, and the demand regime is called wage-led. If the effect is positive, it is called profit-led. The question whether the negative effect of lower wages on consumption or the positive effect on investment and net exports is larger is an empirical issue.

Empirical research that have tried to identify these opposite effects (e.g. Hein and Vogel, 2008; Stockhammer et al., 2009; Onaran and Galanis, 2012) suggest three important findings: Firstly, consumption reacts more sensitively to a decrease in the wage share than does investment, hence domestic demand (consumption and investment) is wage-led in all countries. The character of the demand and growth regimes thus depends crucially on the relevance of the net export effects. Secondly, the effects via the international trade channel depend on the elasticity of exports and imports to prices and labor costs as well as the degree of trade openness. Relatively closed large economies (like the US and Germany) tend to be wage-led as opposed to relatively small open economies, where net exports may play a major role in determining the overall outcome. Thirdly, in a large region like the Eurozone or in the current state of high international integration in the

\footnotetext{
${ }^{6}$ The rise in personal income inequality is also expected to have a negative effect on consumption, since the marginal propensity to consume out of high income is lower than that out of low income.
} 
world economy the international competitiveness effects of declining wage shares are eliminated when the fall in the wage share takes place simultaneously across all countries.

The findings related to the Eurozone are particularly interesting: even when individual small countries may be profit-led (e.g. Austria or Netherlands), large countries in the region tend to be wage-led (e.g. France and Germany). Furthermore, since wage shares fell simultaneously in all countries, there is little advantage of this for the net export position of each country because extra-Eurozone trade is comparatively small. ${ }^{7}$ The result is that domestic effects dominate the outcome when all Eurozone countries pursue "beggar thy neighbor" policies, because the international competitiveness effects are negligible. A decrease in the wage share in the Eurozone as a whole thus leads to lower growth rate (Onaran and Galanis, 2012).

The expected outcome of the race to the bottom in the wage share in the global economy since the 1980s should, therefore, have been a stagnation of global demand and growth. So how did the world economy or individual countries managed to grow prior to the Great Recession? A stagnation in demand was circumvented by two distinct growth models: (i) a debt-led growth model in the US, UK, Australia in the core, and in the periphery in the GIPS and Eastern Europe; and (ii) an export-led growth model in Germany, Austria, and Japan in the core. The debt-led and the export-led growth models are complementary in that the export-led growth regimes can pursue mercantilist models only in the presence of debt-led deficit countries. Hence both rely on increasing accumulation of debt, and they are both equally fragile reflecting the global imbalances that have grown dramatically in the 2000s; the unsustainability of these global imbalances became evident in the aftermath of the Great Recession.

\footnotetext{
${ }^{7}$ Roughly two thirds of the external trade of Euro member states is within the Eurozone.
} 
At the root of both models lie different ways to react to the same chronic domestic demand deficiency due to declining wage shares. The way different countries dealt with this potential crisis of demand depended on their structural parameters regarding their position in the global value chains, history of industrial policies, employment relations, and differences in financialization. Financial deregulation of the 1980s and the role of the financial industry were strongest in the US and the UK. In the periphery of Europe, European integration and the liberalization of capital flows was determinant in making debt-led growth feasible.

International financial deregulation made persistent long-term current account imbalances in the debt-led growth regimes feasible without major currency adjustments, which were in return financed by capital inflows from the export-led countries with persistent current account surpluses. In 2007, for example, Germany had a current account surplus of $7.5 \%$ of GDP, while the US had a deficit of $5.1 \%$. After the liberalization of capital flows exchange rates were not adjusting to trade imbalances but were determined by capital flows chasing financial return. International financial liberalization has thus created the conditions for debt-led and export-led growth models to co-exist for extended periods as long as the financial investors find the debt situation in the debtled growth models sustainable.

As discussed in Section 2, within the Eurozone itself, the crisis laid bare former divergences caused by the process of European Monetary and Economic Unification. Productivity and production structures did not converge, and although inflation rates came down in all countries, the countries that had low inflation prior to the Euro also had lower inflation rates afterwards. This has led to the increasing divergence of nominal unit labor costs (Stockhammer and Onaran, 2012) and resulted in sizable current account disequilibria across the Eurozone, which are mostly due to imbalances within the Eurozone rather than with countries outside Europe. 
Hence Southern and Eastern periphery of Europe has experienced massive capital inflows for more than a decade from the trade surplus countries, most of all Germany. As a result, massive external liabilities have been accumulated in the trade deficit countries, which financed debt-led spending. In Greece it was mostly the government sector that accumulated debt, in Ireland, Portugal, and Spain it was rather the private sector, and in particular the household sector (Lapavitsas et al., 2010) - between 2000 and 2008 private household debt increased by 26\%-points in the US, 28\%-points in the UK, and 61.7, 21.3 and 32.5\%-points in Ireland, Portugal and Spain respectively, whereas it shrank in Germany by 11.3\%-points (Stockhammer, 2013a).

In the debt-led countries, growth driven by increasing debt, financed by capital inflows led to asset and/or property price bubbles, which fuelled the increase in debt via equity withdrawals. In the export-led countries, on the contrary, net exports have provided the main driving force for demand. In the extreme case of Germany, three quarters of GDP growth has been driven by net exports since 2000 (Stockhammer and Onaran, 2012).

How far does our argument differ from the existing literature? To begin with, most mainstream economics regards the crisis foremost as a financial issue (e.g. Blanchard, 2009; Brunnermeier, 2009; Roubini and Mihm, 2010), while distributional considerations are often disregarded. There are some exceptions though. Rajan (2010) contends that skill-biased technological change increased permanent inequality in the US, and, induced the US government to encourage credit growth in general and the subprime mortgage market in specific to expand consumption. Stiglitz $(2009 ; 2011 ; 2012)$ also argues that aggregate demand would have been insufficient without a rise in private debt levels that "fuelled a consumption boom that allowed Americans to live beyond their means" (Stiglitz, 2012, p.54). In contrast to Rajan, for Stiglitz the main reasons for this situation were that poor and middle-income households tried to keep up with 
the richer parts of the society, and that rent seeking and asymmetric information led to market distortions.

Kumhof and Ranciere (2010) develop a dynamic stochastic general equilibrium (DSGE) model with investors and workers, in which an increase in inequality results in rising debt of workers that is financed from savings from investors. As workers become over-indebted, the number of defaults increases, and, finally, a financial crisis emerges. A shortcoming of this model is that it does not involve asset and property price bubbles and that lending is solely driven by savings. In none of these mainstream contributions the emergence of different growth regimes and of a role of inequality in contributing to balance of payment imbalances are central. The only exception is Kumhof et al. (2012), who extend the Kumhof and Ranciere (2010) model to a two country case where the rich population in countries with less developed financial markets finances the rising debt of the poor population in countries with more developed financial markets. However, this paper does not focus on the existing imbalances within the Eurozone, and it does not explain why countries with highly developed financial markets (like Germany) also have financed the poor population in other countries.

Among Post-Keynesian and Marxian economists the issue of income distribution has featured more prominently and several authors have offered analyses that substantially overlap with ours (e.g. Barba and Pivetti, 2009; Foster and Magdoff, 2009; Horn and van Treeck, 2011; Palley, 2012; van Treeck and Sturn, 2012; Behringer and van Treeck, 2013; Cynamon and Fazzari, 2013; van Treeck, 2014). ${ }^{8}$ In contrast to our analysis, most of the Marxist literature concentrates on overproduction - a surplus of capital with a lack of investment opportunities -, rarely

\footnotetext{
${ }^{8}$ The importance of inequality is contested among heterodox economists. Some Marxists regard a declining profit rate as the prime cause underlying the crisis (see e.g. Freeman, 2010; Kliman, 2012), although Dumenil and Levy (2011) and Basu and Vasudevan (2013) report that profit rates recovered in the neoliberal period. Many Post-Keynesians concentrate on financial regulation and/or Minskian instability to explain the financial crisis (see e.g. Kregel, 2008; Crotty, 2009; Wray, 2009).
} 
distinguishes between different growth regimes and mainly focuses on US developments. Exceptions are Brenner (2009), Dumenil and Levy (2011), Lim and Khor (2011) and Vidal (2013) who discuss international imbalances and the importance of debt-led growth. Nevertheless the imbalances within the Eurozone are not discussed in relation to inequality. ${ }^{9}$ This is also true for the above listed Post-Keynesian studies.

We regard the two studies by Hein (2012) and Hein and Mundt (2012) closest to ours. Both identify rising inequality, rising household debt, global imbalances, and financial deregulation as the main causes of the financial and Eurozone crisis; and they distinguish between debt-led and export-led regimes. Their analysis is also based on a Kaleckian approach. However, the center of their analysis is the effects of financialization rather than income distribution and they do not discuss wealth distribution in much depth, to which we turn in the next section.

\section{Wealth concentration, demand for assets and asset prices}

Prior to the current crisis, not only functional and personal income inequality but also the extent of wealth accumulation at the top increased dramatically. Wealth concentration can be measured in relative and absolute terms. Relative wealth concentration refers to the possession of disproportionate shares of wealth at the top. It is well documented that relative wealth concentration is normally higher than relative income concentration, and that the trend changes in top wealth shares (Figure 4) have been to some extent similar to that of top income shares (Figure

\footnotetext{
${ }^{9}$ Lapavitsas et al. (2010) emphasize the structural contradictions of the Euro as a single currency to explain the imbalances; their focus is not on inequality as a root cause of the sovereign debt crisis in Europe.
} 
3). After World War I the extreme top wealth shares in Europe and the US decreased significantly, while they started to increase again from the late 1970s onwards. ${ }^{10}$ There exists very little data for countries from other regions but estimates suggest that within inequality has increased in most countries during the 2000s and that the global top $1 \%$ share currently is around $46 \%$ of total global wealth (Goda, 2014).

[Figure 4]

In order to analyze the effect of wealth concentration on financial investment demand, it is important to consider changes in the absolute amount of global wealth holdings on the top of the wealth distribution. The amount of absolute wealth holdings is important insofar as they determine how much financial investment demand the wealthy people have, and the global pool rather than wealth in a single country in isolation is the relevant indicator as financial capital is highly mobile. Unfortunately, "official publications do not report estimates of absolute inequality" (Atkinson and Brandolini, 2010, p.3). However, some private wealth reports provide estimates of the amount of global wealth holdings of those individuals who have a net worth of at least US\$1 million (primary residency excluded) - so called high net worth individuals (HNWIs).

According to these reports, between 1986 and 2012 HNWIs' wealth increased 6.6-fold from US\$ 7.2 trillion to US\$ 46.2 trillion - and billionaires' wealth even more than 15 -fold (Goda, 2014). ${ }^{11}$ The increase in absolute wealth concentration was especially steep in the years prior to the crisis. HNWIs' net wealth increased more than 1.5-fold between 2002 and 2007, from US $\$ 26.7$

\footnotetext{
10 The data presented in Figure 3 is mainly based on estate tax data. Some data sources that are based on household survey data suggest that the increase of top income shares was not as pronounced as that presented in Figure 3 (see e.g. Wolff, 2010 for the US). It is likely that much of this discrepancy can be explained by top-coding, sampling errors, non-responses, and misreporting (Vermeulen, 2014).

${ }^{11}$ During the same period global GDP only increased 4.8-fold in current terms.
} 
to US $\$ 41$ trillion $^{12}$, while the global wealth holdings of billionaires increased 2.3 -fold to US $\$ 3.5$ trillion. This growth can be explained partly by the growth of the HNWI population (from 7.3 million to 10.1 million individuals) and partly by the increase of the mean wealth per HNWI (from US\$3.66 million to US\$4.03 million). The tremendous growth in wealth holdings at the top means that Rockefeller today would not be within the top 20 of the global billionaires list and that at the end of 2012 the four wealthiest men -Slim, Gates, Ortega, and Buffet- were more than twice as rich as Rockefeller was in 1937 (Goda, 2014).

One reason for this increase of absolute wealth holdings of HNWIs was an increase in top incomes (Saez and Zucman, 2014). Personal income inequality and wealth concentration tend to be self-reinforcing because high income households save a higher proportion of their income and "wealth has a substantial impact on the share of income earned by those in the top 0.5 percent of the [adjusted gross income] distribution" (Tuttle and Gauger, 2006, p.506). Another reason for this exceptional increase in wealth concentration was the sharp increase of global stock market prices and real estate values, since increasing asset prices automatically translate into higher wealth holdings of their owners, who mainly belong to the richest segment of the population (Wolff, 2010).

In contrast to income inequality, few studies discuss possible economic effects of the increase in absolute wealth accumulation at the top. Froud et al. (2001) argue that household savings from the richer parts of the US and UK society are increasingly invested in existing financial securities rather than the real sector. The result is that companies cannot generate enough returns to satisfy investors' profit expectations. This 'symptom of low returns' forces companies (i) to divert their activities into areas with higher returns, and (ii) to boost their share prices, both

\footnotetext{
12 Different definitions and estimates of HNWIs' wealth holdings exist (see Goda (2014) for an in-depth discussion). The figures presented in the text are lower bound estimates of HNWIs' wealth.
} 
of which lead to a 'coupon type of capitalism' in which the financial sector becomes more and more important and stock market bubbles are building-up. Similarly, Wisman and Baker (2012) and Wisman (2013, p.922) claim that by "seeking profitable outlets for its dramatically increased income and wealth, the elite fuelled first a stock market boom and then, after the high-tech bubble burst, a real-estate boom" in the US. Between 1997 and 2007 increasing global wealth holdings went hand in hand with a sharp increase in stock market and housing prices in the US and the Eurozone. An indication that the former was driving the latter is that global wealth holdings were increasing continuously and to a stronger degree than the asset prices in the US and Eurozone (Figure 5). The resulting price rally in stock and real estate markets, in turn, contributed to the existence of the above discussed debt-led growth regime in the US, the UK and GIPS countries ${ }^{13}$ as they provided greater collateral to low- and middle-income households, which enabled them to accumulate increasing debt.

[Figure 5]

Political economists also have acknowledged that the toxic securities that triggered the crisis were partly created because "there is a growing 'wall of money' facing global financial markets that is looking for investment opportunities" (Engelen et al., 2010, p. 47), which means that the crisis "is also a story of the financialization of consumer credit networks [that enabled] lenders of all kinds to generate new assets" (Langley, 2008, pp. 136-137). However, in these discussions wealth concentration normally is not mentioned but instead emphasis is laid on rising asset demand from

\footnotetext{
${ }_{13}$ Between 1997 and 2007, stock market prices increased by 320\% in Greece, 280\% in Spain, 220\% in Portugal and 190\% in Ireland, while house prices rose by $350 \%$ in Ireland, 300\% in Spain, and $250 \%$ in Greece.
} 
institutional investors, governments and sovereign wealth funds. This is clearly a shortcoming, given the above discussed increase in wealth concentration at the top and the fact that in 2007 HNWIs had more asset under management (US\$41 trillion) than global pension funds (US\$28 trillion), mutual funds (US\$26 trillion) and insurance companies (US\$20 trillion) (IFSL, 2008). Two authors that have addressed this shortcoming are Milanovic (2011) and Wisman (2013), although in a different manner. Milanovic states that "[h]igh-net-worth individuals and the financial sector were ... keen to find new lending opportunities" (p.195) to overcome a shortage of investment opportunities, while Wisman (2013, p.940) argues that "investment funds were being switched from production to speculation, which stimulated innovations in credit instruments". However, both authors do not specify a concrete transmission mechanism. Lysandrou (2011a; 2011b) is the first author to theorize the link between the increase in absolute wealth concentration and CDO production in more detail. His argument is that the increasing financial investment demand from HNWIs contributed to a global shortage of investible securities. To alleviate this shortage the market for CDOs was rapidly expanded. Lysandrou does not provide empirical evidence for his claim though. To give credibility to this theory it needs to be shown that (i) one driving force behind the mortgage securitization growth was a fall in the yield of traditional debt securities, (ii) HNWIs contributed to this fall, and (iii) these individuals also created a demand pressure for CDOs.

Evidence regarding the first point has been provided by Caballero et al. (2009), Bernanke (2011), and Goda et al. (2013). Especially after 2000 many emerging market economies (EMEs) were experiencing high growth rates, but their debt security market could not keep up with this development. EMEs' bond markets stayed 'underdeveloped;' at the end of 2007 the EMEs' share in global GDP was one-third whereas their share in world debt security markets was only ten 
percent (IMF, 2008). Due to this global mismatch investors were increasingly 'forced' to invest in the US where most financial assets are produced (Caballero and Krishnamurthy, 2008). The resulting capital inflows not only helped to finance the debt-led growth model of the US, but also led to the phenomena that the supply of traditional investment grade debt securities could not keep up with the growing global demand for these securities. Government purchases from export surplus countries like China lowered long term yields of US Treasury and agency bonds, while foreign and domestic private investor demand reduced US agency, corporate, and municipal bonds yields (Bernanke, 2011; Bertaut et al., 2012; Goda et al., 2013). The depressed yields, in turn, led to a search for alternative debt securities with a higher yield. Various studies have therefore concluded that "an excess safe asset demand on the part of investors was a chief force that drove the expansion of the US CDO market well beyond what was prudent" (Goda et al., p.135).

But, in how far were HNWIs involved in this global excess demand? To answer this question, Goda and Lysandrou (2014) estimates the size of HNWIs' US bonds holdings and their involvement in the demand pressure. According to their findings, more than half of HNWIs wealth is comprised of financial securities of which around half is comprised of debt securities. Moreover, HNWIs bond holdings are heavily skewed towards the US market which is by far the biggest and most liquid market in the world. The rise in HNWIs wealth holdings thus meant that global HNWIs increased their total holdings of US bonds by around forty percent between mid-2004 (US\$2.1 trillion) and mid-2007 (US\$2.9 trillion). ${ }^{14}$ This increase was restricted to US agency, corporate and municipal bonds, whereas their US Treasury holdings declined slightly. This pattern can be explained by the fact that private investors were squeezed out of the latter market due to the steeply

\footnotetext{
${ }^{14}$ Goda and Lysandrou (2014) estimate that around $60 \%$ of US individual bond holdings were held by US HNWIs prior to the crisis, while $20 \%$ to $30 \%$ of foreign private bond holdings stemmed from rest of the world HNWIs. Different estimates by Hager (2014) confirm that US bond holdings are concentrated in the hands of the top $1 \%$ of the population.
} 
increasing demand for Treasuries from foreign governments (especially from China). The rise in HNWIs non-Treasury bond holdings meant that very rich individuals depressed long-term bond yields of AAA-rated US agency, corporate and municipal bonds "to a similar degree as changes in business cycle expectations, interest rate volatility and default risk" (Goda and Lysandrou, 2014, p.13). This result suggests that HNWIs significantly contributed to the above mentioned shortage of traditional debt securities, which triggered a 'search for yield' by all global investors that helped to encourage the demand for CDOs.

As regards the third point it has to be shown that HNWIs also were involved in the demand pressure for CDOs. Rich investors were not directly involved in this market, but indirectly via hedge funds, who held nearly half of all issued CDOs by June 2007 (Blundell-Wignall, 2007). The absence of rich individuals' direct involvement most likely can be explained by the complex nature of $\mathrm{CDOs}^{15}$, whereas the dominant position of hedge funds can be mainly explained by two factors: (i) the exceptional growth of this industry ${ }^{16}$, and (ii) the pressure that they faced to generate above average yields by the investors whose funds were managed by the hedge funds. An important driver behind this growth and pressure was the increasing investment of HNWIs, who increased their hedge fund assets approximately from US $\$ 500$ billion to US $\$ 1,1$ trillion between 2002 and 2007 (Goda and Lysandrou, 2014).

Hedge fund managers were contented with their growing asset base, but it also provided them with a problem. To maximize returns hedge funds rely on leverage, and to get access to cheap

\footnotetext{
${ }^{15}$ An owner of ordinary government and debt securities can easily find out how risky the investment is and in how far the risk of default changes over time. The same is true for asset-backed security (ABS) investors as the backing collateral normally also consists of a single, homogenous class of assets. CDOs, by contrast, do not meet this transparency criterion as they are backed by many different types of asset classes (in their simplest form a CDO is an ABS of many ABS). That is why each CDO's price is negotiated over the counter by the seller and the buyer, i.e. in contrast to conventional fixed income securities, CDOs have no standard prices. As a result, "wealthy individuals did not have the requisite expertise to participate [directly] in this market" (Lysandrou, 2011-12, p.227).

${ }^{16}$ Hedge funds' assets under management more than tripled between 2002 and 2007, reaching US\$2.2 trillion in 2007.
} 
credits they need to provide investment grade collateral to banks. Given that investment grade bonds had historical low yields, hedge funds needed to find an alternative that was accepted by banks and at the same time kept borrowing costs to a minimum. CDOs were the solution to this problem. Their senior tranches could be used as collateral that gave a decent return, while their equity tranches were seen as high yielding investment opportunity whose risk could be controlled by using put options and credit default swaps ${ }^{17}$. This strategy allowed hedge funds to generate an above average return for their clients and high bonus payments for themselves, and at the same time generated demand for banks to supply increasing amounts of CDOs. This analysis suggests that the historical high level of absolute wealth concentration is crucial to explain why the CDO market reached a size that was sufficiently large to endanger the global financial system when it collapsed in August 2007.

\section{Synthesis}

Rising income inequality and wealth concentration have contributed to the crisis in complex but essential ways. Figure 6 summarizes our argument. Rising income inequality has led to potentially stagnant demand, because the world economy overall is in a wage-led demand regime. In Neoliberalism this has been overcome via either debt-led or export-led growth models. The debtled growth model relied on asset and property bubbles to generate credit that ultimately fuelled consumption. This allowed working class households to maintain growing consumption while

\footnotetext{
${ }^{17}$ Put options enabled hedge funds to sell an equity tranche at a specified date at a specified price. Credit default swaps gave hedge funds the right to be compensated in the case of default.
} 
their incomes stagnated (in particular in the US and the UK). These countries usually had large current account deficits and effectively played the role of a growth engine of the world economy. The export-led growth model had stagnant domestic demand and used net export growth as the source of demand growth. Both growth models are intrinsically unstable, since they both rely on increasing debt to income ratios. In the debt-led model household debt has risen to allow for growth. However, the export-led growth model also relies on rising debt, but it is not domestic debt, but rising foreign debt of its trade partners. The debt-led and export-led growth models are thus complementary and they result in rising household debt, international imbalances and rising international debt.

[Figure 6]

Rising wealth concentration played an important role in providing the finance for these unstable growth regimes. Rich households (or their trusts) save differently from working class households: they save a higher share of their income and hold riskier assets. The superrich, or more technically, HNWIs, played a crucial role in that (i) their increasing asset demand helped to lower the yield of traditional bond classes, which put pressure on investors to seek alternative investment grade fixed income securities that provided higher yields, and (ii) HNWIs were the main investors in hedge funds ${ }^{18}$, which, in turn, were the main buyers of CDOs. HNWIs thus helped to create the institutions that aggressively developed new financial instruments and, ultimately, they provided the funding for subprime loans and growing credit more broadly. Economic inequality thus played

\footnotetext{
${ }^{18} \mathrm{HNWIs}$ remained the main investor in hedge funds throughout the whole pre-crisis period despite the increasing involvement of institutional investors in this market (Lysandrou, 2011b).
} 
a crucial role on both the supply and demand sides of the market of the toxic securities that were at the epicenter of the crisis.

Overall, many elements of our argument can be found in the literature. In particular the link between income inequality and rising household debt has become widely accepted among many Post-Keynesians and Marxians and is also discussed at the critical fringes of the mainstream (as discussed in Section 3). The emergence of debt-led versus export-led growth regimes and the impact of wealth concentration on financial (in)stability are much less widely recognized though, and most of the literature focuses on the US. Our approach differs in various ways. Firstly, our internationally comparative analysis exposes that countries have relied on debt- or export-led growth models in order to deal with the rise in inequality. Secondly, we systematically highlight the link between inequality and demand formation in the real and the financial sector. To our best knowledge our study is the first that that integrates the analysis of income inequality and wealth concentration and its effects on consumption and debt levels, balance of payment imbalances, and financial innovation. Finally, our paper is the first that discusses in detail the link between debtand export-led growth regimes, wealth concentration, and the Eurozone crisis.

Several topics for future research emerge: First, the interaction between the different growth regimes needs further analysis. In particular the contribution of capital inflows to asset and property price bubbles in advanced economies is under-researched. Second, the effect of inequality on the growing demand for financial innovation, speculation and fragility deserves a lot more attention than it has hitherto received. Third, there is need to develop macroeconomic models that explicitly deal with the link between income distribution, asset prices and wealth distribution. 


\section{Policy recommendations}

An important policy implication arising out of this analysis is that a more egalitarian distribution of income is not a luxury that can be taken care of once the crisis and regulatory issues have been resolved, but that it is necessary to reverse the actual level of absolute wealth concentration and income inequality to help contain the inherent problems of the current mode of capitalism. Given that income inequality and absolute wealth concentration have increased further since the outbreak of the crisis (OECD, 2013; Goda, 2014), decisive government intervention seems necessary to achieve this aim.

The policy mix requires both the restoration of the link between productivity and real wage growth and progressive taxes and social policies. Hence minimum wages should increase automatically in line with inflation and productivity and the bargaining power of workers should be strengthened through changes in the union legislation and collective bargaining coverage as well as strengthening the welfare state and taming the mobility of capital and regulating finance.

With regard to taxes, we agree with Piketty (2014) that a wealth tax is needed. Additionally, top marginal income and estate taxes should be raised. An indexation of these taxes would be an appropriate solution to avoid very high concentrations of income and wealth. One possible rule would be to link top income and wealth taxes to median incomes and wealth holdings. Possible thresholds for developed countries could be a highest marginal tax rate of $70 \%$ for income above 10 times the median income, of $10 \%$ on all personal net wealth (excluding primary residence) that is above 100 times the median wealth, and of $90 \%$ for all inheritance that are above 100 times the median wealth. 
This proposal might seem very radical at first sight, but it is not. In the four decades before Margaret Thatcher and Ronald Reagan came to power the UK and the US had top marginal income tax rates of at least $70 \%$ and wealth taxes were common in OECD countries. As existing governance arrangements allow the rich to be highly mobile and secretive, these policies need to be implemented on a global or at least regional scale. Moreover, tax avoidance and evasion opportunities have to be closed off through the implementation of tougher regulations. The accruing new government revenues should be used for public services like education, health, care services for children and elderly, the reduction of value added taxes for non-luxury goods, and for green investment programs. 


\section{References}

Acharya, V.V., Drechsler, I. and Schnabl, P. (2011). 'A pyrrhic victory? Bank bailouts and sovereign credit risk'. NBER Working Paper, No.17136.

Akerlof, G.A. and Shiller, R.J. (2009). Animal Spirits: How human psychology drives the economy, and why it matters for global capitalism. Princeton: Princeton University Press.

Arestis, P. and Sawyer, M. (2011). The ongoing Euro crisis. Challenge, 54(6): 6-13.

Ashcraft, A.B. and Schuermann, T. (2008). 'Understanding the securitization of subprime mortgage credit'. Federal Reserve Bank Staff Report, No.318.

Atkinson, A.B. and Brandolini, A. (2010). On Analyzing the World Distribution of Income. The World Bank Economic Review, 24(1): 1-37.

Atkinson, A.B., Piketty, T. and Saez, E. (2011). Top incomes in the long run of history. Journal of Economic Literature, 49(1): 3-71.

Barba, A. and Pivetti, M. (2009). Rising household debt: its causes and macroeconomic implications-a long-period analysis. Cambridge Journal of Economics, 33(1): 113-37

Basu, D. and Vasudevan, R. (2013). Technology, distribution and the rate of profit in the US economy: understanding the current crisis. Cambridge Journal of Economics, 37(1): 57-89

Behringer, J. and van Treeck, T. (2013). 'Income distribution, aggregate demand and current account: A sectoral perspective'. IMK Working Paper, No.125.

Bernanke, B. (2011). International capital flows and the return to safe assets in the United States. Banque de France Financial Stability Review, 15, 13-26.

Bertaut, C., Pounder DeMarco, L., Kamin, S.B. and Tryon, R.W. (2011). ABS inflows to the United States and the global financial crisis. Journal of International Economics, 88(2): 219-34.

Bhaduri, A. and Marglin, S. (1990). Unemployment and the real wage: the economic basis for contesting political ideologies. Cambridge Journal of Economics, 14(4): 375-93.

Blanchard, O. (2009). 'The Crisis: Basic Mechanisms, and Appropriate Policies', IMF Working Paper, No.WP09/80.

Blundell-Wignall, A. (2007). Structured products: implications for financial markets. Financial Market Trends, 93(2): 27-57.

Brenner, R. (2009). What is good for Goldman Sachs is good for America. The origins of the current crisis. available at http://www.sscnet.ucla.edu/issr/cstch/papers/ BrennerCrisisTodayOctober2009.pdf.

Brunnermeier, M. (2009). Deciphering the liquidity and credit crunch 2007-2008. Journal of Economic Perspectives, 23(1): 77-100.

Caballero, R.J. and Krishnamurthy, A. (2009). Global Imbalances and Financial Fragility. American Economic Review, 99(2): 584-88.

Caballero, R.J., Farhi, E. and Gourinchas, P.-O. (2008). Financial crash, commodity prices and global imbalances. Brookings Papers on Economic Activity, 39(2): 1-55.

Costa, J. and Ricciuti (2013). 'Sources for the Euro Crisis: Bad Regulation and Weak Institutions in Peripheral Europe'. University of Verona Department of Economics Working Paper, No.15.

Crotty, J.R. (2009). Structural causes of the global financial crisis: a critical assessment of the 'new financial architecture'. Cambridge Journal of Economics, 33(4): 563-80. 
Crotty, J.R. (2012). The great austerity war: what caused the US deficit crisis and who should pay to fix it?. Cambridge Journal of Economics, 36(1): 79-104.

Cynamon B. and Fazzari, S. (2013). 'Inequality and household finance during the consumer age'. Levy Economics Institute Working Paper, No.752.

Dafermos, Y. and Papatheodorou, C. (2011). 'Functional and Personal Income Distribution in a Stock-Flow Consistent Model'. 15th Conference of the Research Network Macroeconomics and Macroeconomic Policies, Berlin, 28-29 October.

Daudey, E. and Garcia-Penalosa, C. (2007). The Personal and the Factor Distributions of Income in a Cross-Section of Countries. Journal of Development Studies, 43(5): 812-29.

Davies, H. (2010). Global Financial Regulation after the Credit Crisis. Global Policy, 1(2): 185-90.

Dumenil, G. and Levy, D. (2011). The Crisis of Neoliberalism. Cambridge (MA): Harvard University Press.

Engelen, E., Erturk, I., Froud, J., Leaver, A. and Williams, K. (2010). Reconceptualizing financial innovation: frame, conjuncture and bricolage. Economy and Society, 39(1): 33-63.

Foster J.B. and Magdoff F. (2009). The Great Financial Crisis: Causes and Consequences. New York: Monthly Review Press.

Freeman, A. (2010). Marxism without Marx: a note towards a critique. Capital \& Class, 34(1):84-97.

Froud, J., Johal, S., Haslam, C. and Williams, K. (2001). Accumulation under conditions of inequality. Review of International Political Economy, 8(1): 66-95.

Galbraith, J.K. (1975). The great crash 1929. Boston: Houghton Mifflin.

Gilens, M. and Page, B.I. (2014). Testing Theories of American Politics: Elites, Interest Groups, and Average Citizens. Perspectives on Politics, forthcoming.

Goda, T. (2013). 'Changes in income inequality from a global perspective: an overview'. PKSG Working Paper, No.PKWP1303.

Goda, T. (2014). 'Global trends in relative and absolute wealth concentration'. CIEF Working Paper, No.14-01.

Goda, T. and Lysandrou, P. (2014). The contribution of wealth concentration to the subprime crisis: a quantitative estimation. Cambridge Journal of Economics, 38(2): 301-27.

Goda, T., Lysandrou, P. and Stewart, C. (2013). The Contribution of US Bond Demand to the US Bond Yield Conundrum of 2004 to 2007: An Empirical Investigation. Journal of International Financial Markets, Institutions \& Money, 27, 113-36.

Golub, S., Kaya, A. and Reay, M. (2014). What were they thinking? The Federal Reserve in the run-up to the 2008 financial crisis. Review of International Political Economy, DOI:10.1080/09692290.2014.932829.

Hager, S.B. (2014). What Happened to the Bondholding Class? Public Debt, Power and the Top One Per Cent. New Political Economy, 19(2): 155-82.

Hein, E. (2012). The macroeconomics of finance-dominated capitalism - and its crisis. Cheltenham: Edward Elgar.

Hein, E. and Mundt, M. (2012). 'Financialisation and the Requirements and Potentials for Wageled Recovery-a Review Focussing on the G20'. ILO Working Papers, Conditions of Work and Employment Series, No.37.

Hein, E. and Vogel, L. (2008). Distribution and growth reconsidered -empirical results for six OECD countries. Cambridge Journal of Economics, 32(3): 479-511.

Hoque, H. (2013). From the credit crisis to the sovereign debt crisis: Determinants of share price performance of global banks. International Review of Financial Analysis, 30, 334-50. 
Horn, G. and van Treeck, T. (2011). Ungleichheit und aussenwirtschaftliche Ungleichgewichte. Eine Keynesiansiche Erklärung. In Helmedag, F. and Kromphardt, J. (eds.): Nachhaltige Wege aus der Finanz- und Wirtschaftskrise. Marburg: Metropolis, 19-37.

IMF (2008). Global Financial Stability Report: Financial Stress and Deleveraging. Washington D.C.: IMF.

King, J, 2002. A History of Post Keynesian Economics since 1936. Edward Elgar

Kliman, A. (2012). The Failure of Capitalist Production: Underlying Causes of the Great Recession. London: Pluto Press.

Kregel, J. (2008). Using Minsky's Cushions of Safety to Analyze the Crisis in the U.S. Subprime Mortgage Market. International Journal of Political Economy, 37(1): 3-23.

Kumhof, M. and Ranciere, R. (2010). 'Inequality, Leverage and Crises', IMF Working Paper, No.268.

Kumhof, M., Lebarz, C., Ranciere, R., Richter, A.W. and Throckmorton, N.A. (2012). 'Income Inequality and Current Account Imbalances'. IMF Working Paper, No.12/08.

Langley, P. (2008). Financialization and the consumer credit boom. Competition \& Change, 12(2): 133-47.

Lapavitsas, C., Kaltenbrunner, A., Lindo, D., Michell, J., Painceira, J.P., Pires, E., Powell, J., Stenfors, A. and Teles, N. (2010). Eurozone crisis: Beggar Thyself and Thy Neighbour. Journal of Balkan and Near Eastern Studies, 12(4): 321-73.

Lavoie, M, 2009. Introduction to Post Keynesian economics. New York: Palgrave Macmillan

Lim, M.-H. and Khor, H.E. (2011). From Marx to Morgan Stanley: Inequality and Financial Crisis. Development and Change, 42(1): 209-27.

Lysandrou, P. (2011-12). The Primacy of Hedge Funds in the Subprime Crisis. Journal of Post Keynesian Economics, 34(2): 225-54.

Lysandrou, P. (2011a). Global inequality as one of the root causes of the financial crisis: a suggested explanation. Economy and Society, 40(3):323-44.

Lysandrou, P. (2011b). Global inequality, wealth concentration and the subprime crisis: A Marxian commodity theory analysis. Development and Change, 42(1): 183-208.

Major, A. (2012). Neoliberalism and the new international financial architecture. Review of International Political Economy, 19(4): 536-61.

Milanovic, B. (2011). The haves and the haves not: A brief idiosyncratic history of global inequality. New York: Basic Books.

OECD (2012). 'Labour Losing to Capital: What explains the declining Labour Share?'. In Employment Outlook, Paris: OECD, Ch.3.

OECD (2013). 'Crisis squeezes income and puts pressure on inequality and poverty'. Retrieved at 12 December 2013 from http://www.oecd.org/social/soc/OECD2013-Inequality-and-Poverty-8p.pdf.

Ohlsson, H., Roine, J. and Waldenström, D. (2008). Long-Run Changes in the Concentration of Wealth: An Overview of Recent Findings. In Davies, J.B. (ed.): Personal Wealth from a Global Perspective. Oxford: Oxford University Press, 42-64.

Onaran, Ö. and Galanis, G. (2012). 'Is aggregate demand wage-led or profit-led? National and global effects'. ILO Conditions of Work and Employment Series, No.40.

Palley, T.I. (2012). From Financial Crisis to Stagnation: The Destruction of Shared Prosperity and the Role of Economics, Cambridge: Cambridge University Press.

Piketty,T. (2014). Capital in the Twenty-First Century. Cambridge Mass: Belknap Press of Harvard University Press 
Rajan, R.G. (2010). Fault Lines. How Hidden Fractures Still Threaten the World Economy. Princeton: Princeton University Press.

Roháć, D. (2011). 'Does inequality matter?'. Adam Smith Institute Briefing Paper, 17 May.

Roine, J. and Waldenström, D. (2009). Wealth Concentration over the Path of Development: Sweden, 1873-2006. Scandinavian Journal of Economics, 111(1): 151-87.

Roubini, N. and Mihm, S. (2010). Crisis Economics: A Crash Course in the Future, New York, Penguin

Saez, E. and Zucman, G. (2014). The Distribution of US Wealth, Capital Income and Returns since 1913. Retrieved at 20 July 2014 from http://gabriel-zucman.eu/files/SaezZucman2014Slides.pdf

Sawyer, M. (2013). Alternative economic policies for the Economic and Monetary Union. Contributions to Political Economy, 32(1): pp. 11-27.

Schuknecht, L., Moutot, P., Rother, P. and Stark, J. (2011). 'The Stability and Growth Pact Crisis and Reform'. ECB Occasional Paper Series, No.129.

Shiller, R. (2012). Don't Resent the Rich, Fix the Tax Code. Retrieved at 14 July 2014 from http://www.bloombergview.com/articles/2012-03-07/don-t-resent-the-rich-fix-the-tax-code-part-3-robertshiller

Shin, H.S. (2012). Global Banking Glut and Loan Risk Premium. IMF Economic Review, 60(2): 155-92.

Solow, R. (2014). The One Percent. Journal of Economic Perspectives, 28(1): 243-48.

Stiglitz, J.E. (2009). The global crisis, social protection and jobs. International Labour Review, 148(1-2): 1-13.

Stiglitz, J.E. (2011). Rethinking macroeconomics: What failed, and how to repair it. Journal of the European Economic Association, 9(4): 591-645.

Stiglitz, J.E. (2012). The price of inequality. London: Penguin Books.

Stockhammer, E. (2011). Peripheral Europe's debt and German wages: the role of wage policy in the Euro area. International Journal of Public Policy, 7(1/2/3): 83-96.

Stockhammer, E. (2013a). Rising Inequality as a cause of the present crisis. Cambridge Journal of Economics, DOI:10.1093/cje/bet052.

Stockhammer, E. (2013b). 'Why have wage shares fallen? A panel analysis of the determinants of functional income distribution'. ILO Conditions of Work and Employment Series, No.35.

Stockhammer, E. 2014. The Euro Crisis and contradictions of Neoliberalism in Europe. PKSG Working Paper 1401

Stockhammer, E. and Onaran, Ö. (2012). Rethinking wage policy in the face of the Euro crisis. Implications of the wage-led demand regime. International Review of Applied Economics, 26(2): 191-203.

Stockhammer, E., Onaran, Ö. and Ederer, S. (2009). Functional income distribution and aggregate demand in the Euro area. Cambridge Journal of Economics, 33(1):139-59.

Taylor, J.B. (2008). 'The financial crisis and the policy responses: An empirical analysis of what went wrong'. NBER Working Paper, No.14631.

Thiemann, M. (2014). In the Shadow of Basel: How Competitive Politics Bred the Crisis. Review of International Political Economy, DOI:10.1080/09692290.2013.860612.

Turner, J.D. (2010). Wealth concentration in the European periphery: Ireland, 1858-2001. Oxford Economic Papers, 62(4): 625-46.

van Treeck, T. (2014). Did inequality cause the U.S. financial crisis?. Journal of Economic Surveys, 28(3): 421-48. 
van Treeck, T. and Sturn, S. (2012). 'Income Inequality as a Cause of the Great Recession? A Survey of Current Debates'. ILO Conditions of Work and Employment Series, No.39.

Vermeulen, P. (2014). How fat is the top tail of the wealth distribution? ECB Working Paper, No.1692.

Vidal, M. (2013). Postfordism as a dysfunctional accumulation regime: a comparative analysis of the USA, the UK and Germany. Work Employment Society, 27(3): 451-71

Wisman, J.D. (2013). Wage stagnation, rising inequality and the financial crisis of 2008. Cambridge Journal of Economics, 37(4): 921-45.

Wisman, J.D. and Baker, B. (2012). 'Rising inequality and the financial crisis of 1929 and 2008'. American University Department of Economics Working Paper, No.2011-01.

Wolff, E. (2010). Recent trends in household wealth in the United States: Rising debt and the middle-class squeezeAn Update to 2007. Levy Economics Institute Working Paper, No.589.

Wolff, E. and Zacharias, A. (2013). Class structure and economic inequality. Cambridge Journal of Economics, 37(6): 1381-1406.

Wray, L.R. (2009). The rise and fall of money manager capitalism: a Minskian approach. Cambridge Journal of Economics, 33(4): 807-28. 


\section{Figures and Tables}

Figure 1: Development of debt, growth and bond yields in the Eurozone, 2007-2013
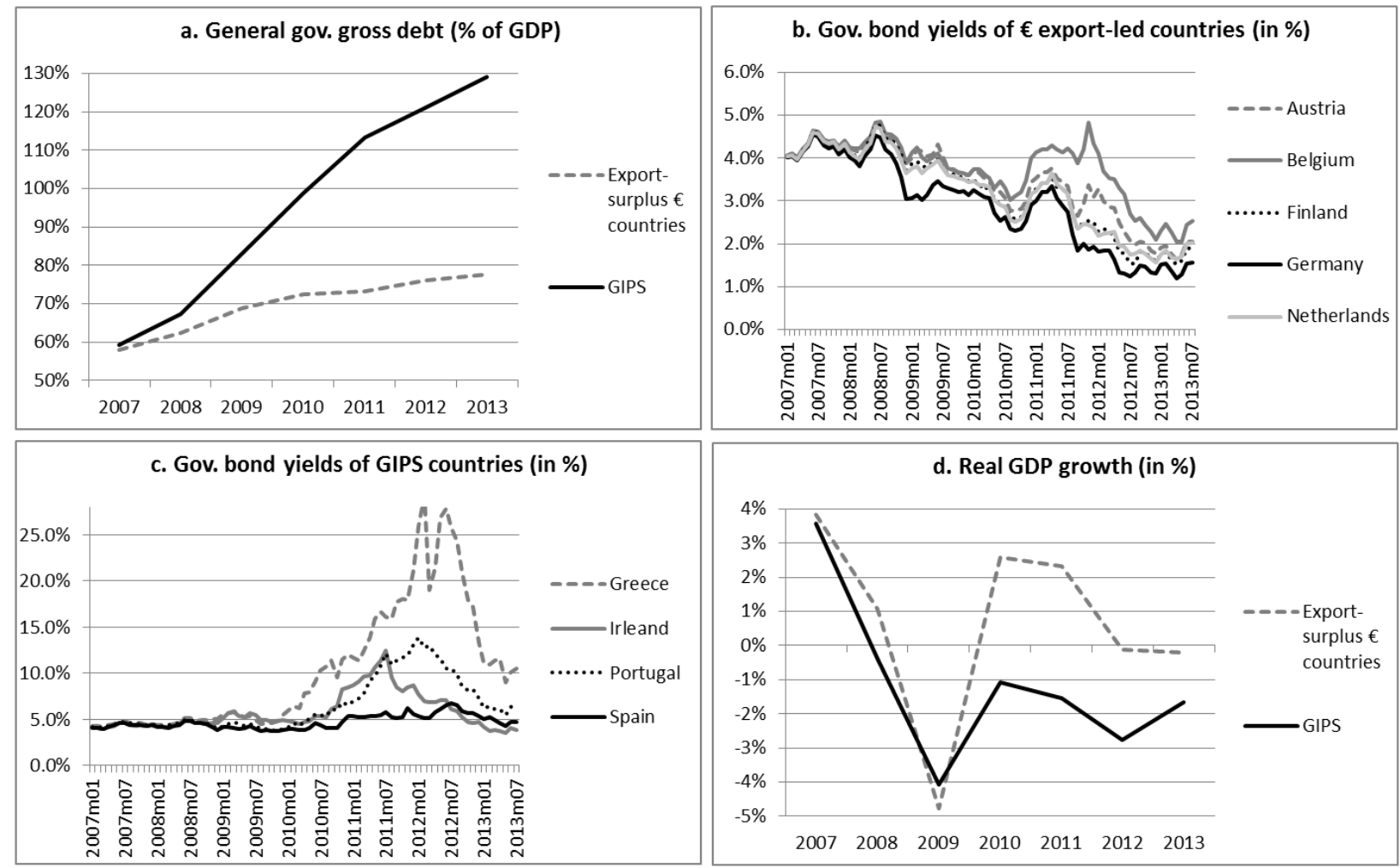

Note: The export surplus countries 1 are Germany, Austria, Netherlands, Belgium and Finland (sources: IMF, WEO, $I M F, I F S)$. 
Figure 2: Wage shares in Western countries, 1960-2013

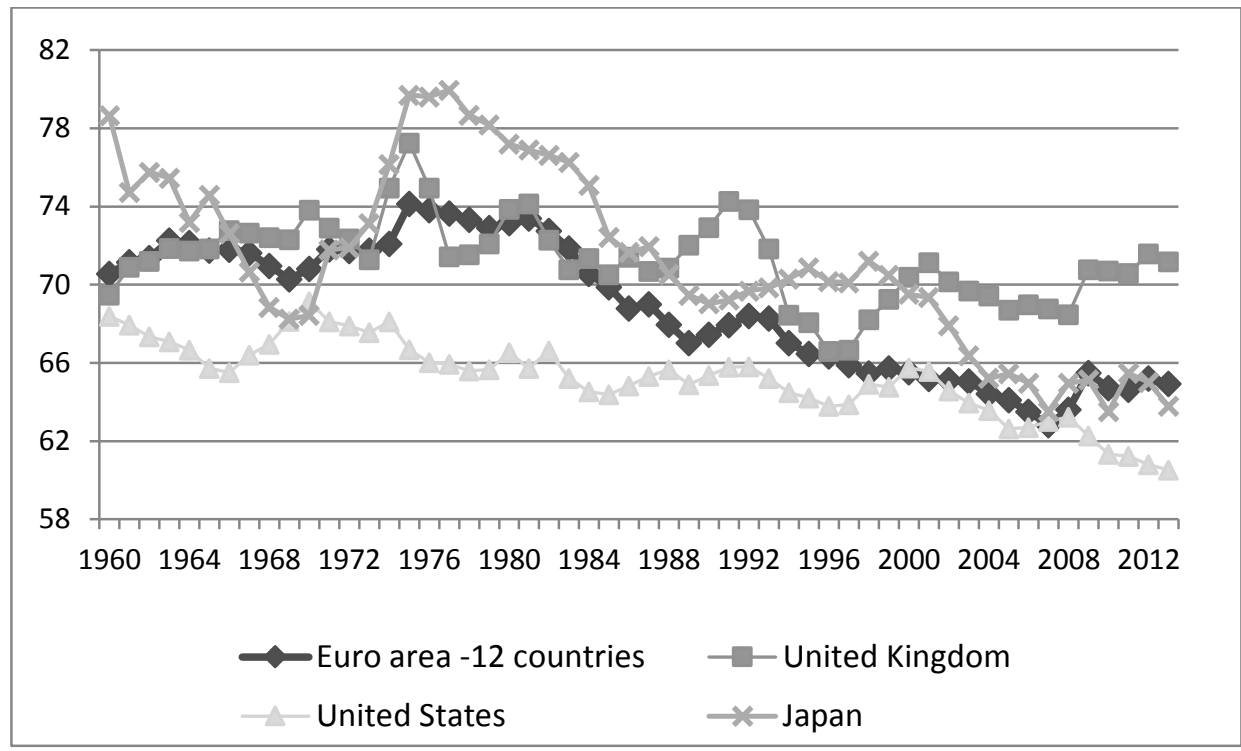

Note: Adjusted, ratio to GDP at factor cost (source: AMECO).

Figure 3: Top 1\% income shares in Western countries, 1886-2012

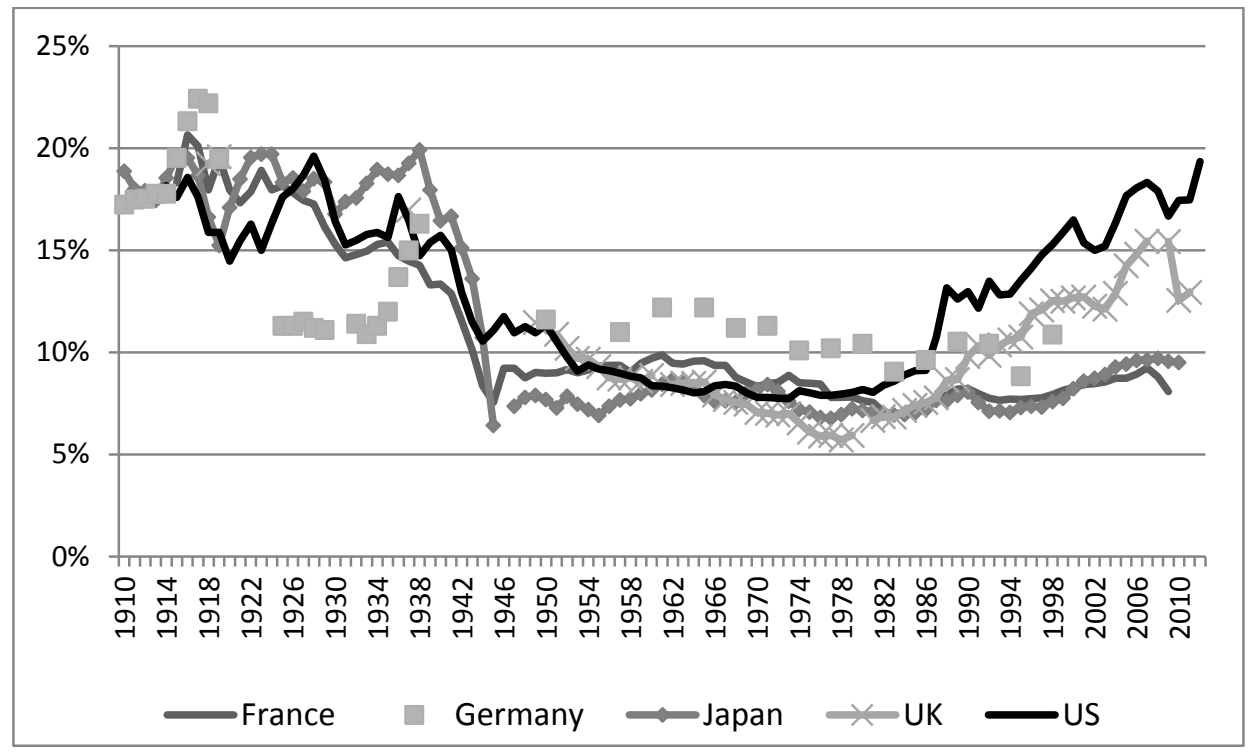

Note: There is a break in the UK series in 1990 (source: World Top Incomes Database). 
Figure 4: Top 1\% wealth shares in Western countries, 1910-2010

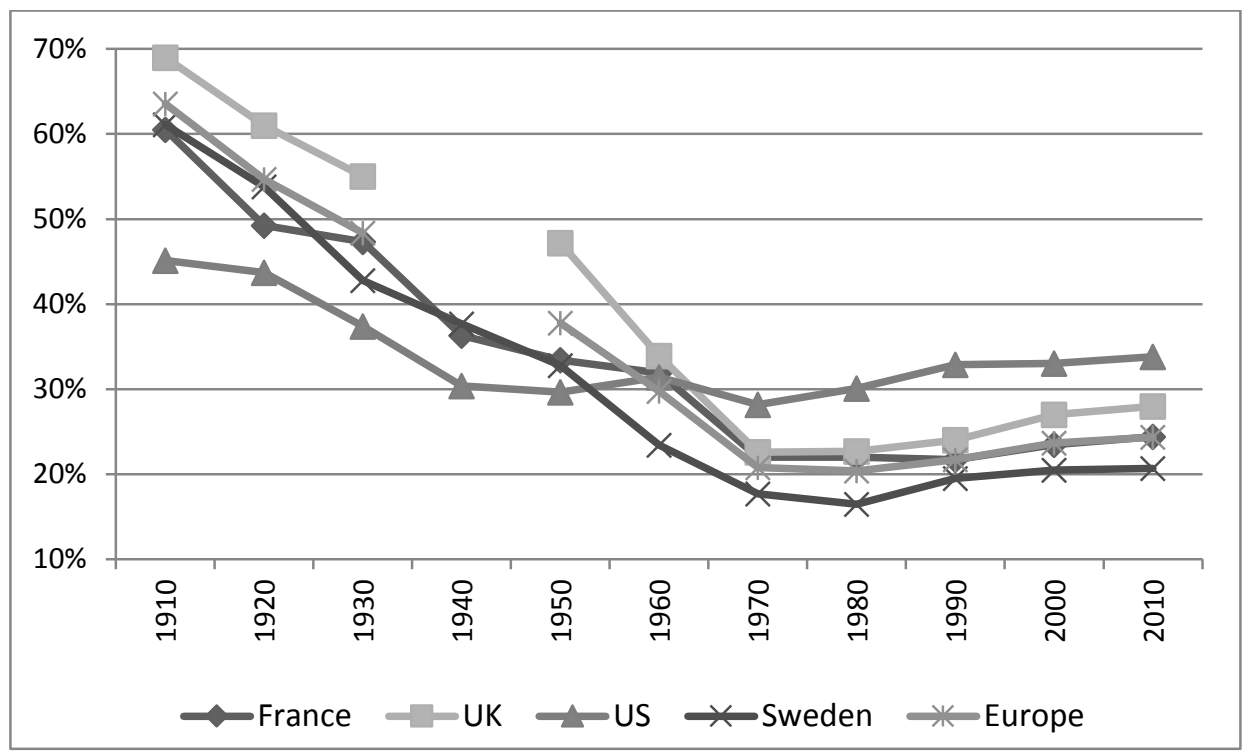

Note: Estimates of inequality of net worth between living adults (source: Piketty (2014)).

Figure 5: HNWIs’ net wealth and asset prices, Index $(1997=100)$

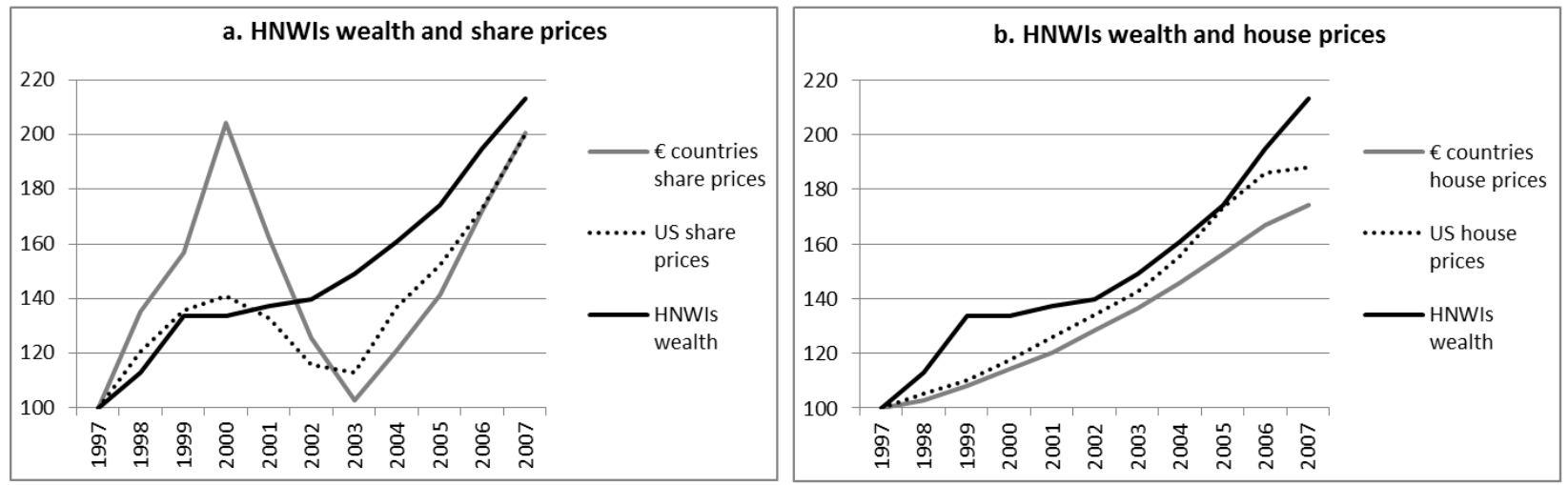

Note: Own calculations based on data from Capgemini \& Merrill Lynch, Dallas Fed; OECD, ECB. 
Figure 6: Income inequality and wealth concentration as contributing factors of the crisis

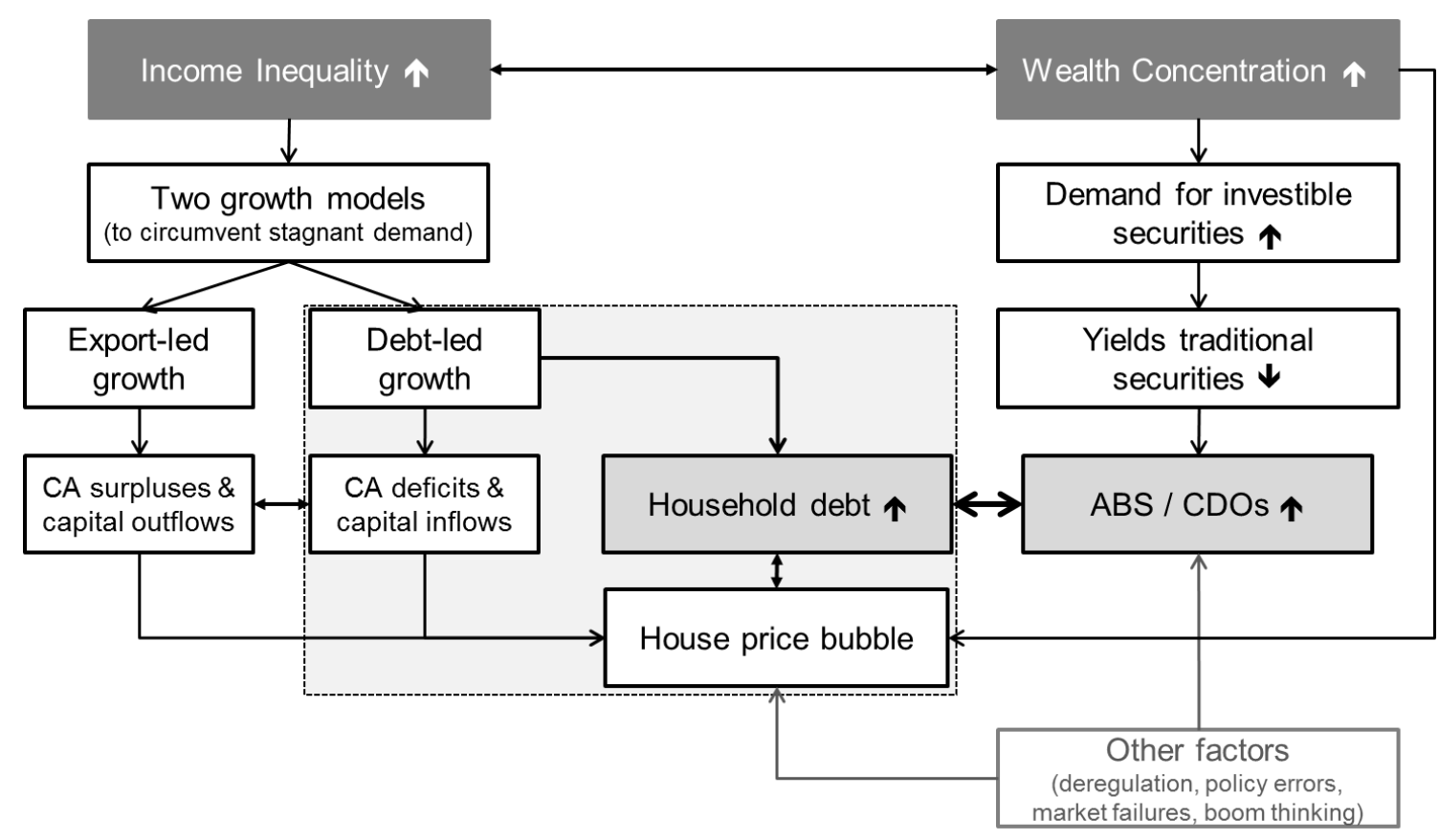

Table 1: Average growth of real GDP in Western countries

\begin{tabular}{|lcccccc|}
\hline & $\mathbf{1 9 6 1 - 6 9}$ & $\mathbf{1 9 7 0 - 7 9}$ & $\mathbf{1 9 8 0 - 8 9}$ & $\mathbf{1 9 9 0 - 9 9}$ & $\mathbf{2 0 0 0 - 0 7}$ & $\mathbf{2 0 0 8 - 1 3}$ \\
Eurozone (12 countries) & 5.3 & 3.8 & 2.3 & 2.1 & 2.2 & -0.3 \\
United Kingdom & 2.9 & 2.4 & 2.5 & 2.2 & 3.2 & -0.3 \\
United States & 4.7 & 3.2 & 3.1 & 3.3 & 2.7 & 0.9 \\
Japan & 10.1 & 5.2 & 4.4 & 1.5 & 1.5 & 0.3 \\
\hline
\end{tabular}

Source: AMECO 